\title{
Ethics in the light of scientific philosophy: understanding Yaman Örs's methodological approach*
}

\section{Billimsel felsefenim ışığında etilk: Yaman Örs'ỉin yo̊ntembilimsel yaklaşımını anlamak}

\author{
Zümrüt ALPINAR ŞENCAN ${ }^{a}$
}

\begin{abstract}
Introduction: Why scientific philosophy? Why Hans Reichenbach? Is there a good reason for us to adopt the methodological approach of scientific philosophy when philosophical activity and ethics is considered? Should the philosophers be held responsible from the judgments they arrive at? According to Yaman Örs (1936-2016), who embraces the approaches of logical positivism, logical empiricism and scientific philosophy, basically as defended by Hans Reichenbach, there is and they should. Yaman Örs, the late prominent bioethicist, has played a crucial leading role in the development of this academic field in Turkey. He has a great number of invaluable works in different fields. But, this paper focuses on his works in which he covered the importance of scientific philosophy for the philosophical activity, the methodology in ethics and the moral issues arising in the field of bioethics and medical ethics. The main aim of this paper is to examine the methodological approach of Yaman Örs as a scientific philosopher and the significant role it plays in ethics and, in part, bioethics. This paper will also signify in detail the importance of the terms, "the ethics of philosophy or philosophizing", "the ethics of philosophers", "the problem sets in bioethics and medical ethics", and "ethics of the professions as differentiated extensions of ethics", all of which seem to be first raised by Yaman Ors and are quite important not only for medical ethics and bioethics, but also for philosophy as an academic field of study.
\end{abstract}

Keywords: yaman örs, scientific philosophy, ethics, the ethics of philosophy, problem sets in bioethics, ethics of the professions as differentiated extensions of ethics.

Giriş ve Amaç: Neden bilimsel felsefe? Neden Hans Reichenbach? Felsefe ve etik dikkate alındiğında, bilimsel felsefenin yöntembilimsel (metodolojik) yaklaşımın benimsememiz için iyi bir nedenimiz var mı? Felsefeciler vardıkları yargılardan sorumlu tutulabilirler mi? Mantıķ̧ı pozitivizm, mantıkçı empirisizm ve Hans Reichenbach'in savunduğu anlamadaki bilimsel felsefe yaklaşımlarmı benimseyen Yaman Örs'e (1936-2016) göre, vardır ve tutulmalıdırlar. Önemli bir biyoetikçi olan Yaman Örs, Türkiye'de bu akademik alanın gelişmesinde oldukça mühim bir role sahiptir. Değişik alanlarda çok sayıda oldukça değerli çalışmaları vardır. Fakat, bu makalede, onun, felsefe için bilimsel felsefenin önemi, etiğin yöntembilimi (metodolojisi) ve biyoetik ve tup etiğinde karşımıza çıkan ahlaki sorunlar konuların kapsayan çalışmaları üzerinde durulmuştur.

\footnotetext{
*The manuscript is based, in part, on the paper "Ethics and Bioethics in Yaman Örs's Scientific Philosophy" presented in EACME, 25th Annual Conference (September 15-17, 2011), Istanbul and on the paper (in Turkish), "Yaman Örs's Approach to Ethics and Bioethics as a Scientific Philosopher", presented in the Turkish Bioethics Association 6th (National) Congress of Medical Ethics: "New Challenges in Bioethics" (November 25-26, 2010), İstanbul.

${ }^{2}$ Postdoctoral Research Fellow, Department of Medical Ethics and History of Medicine, University Medical Center Göttingen, Georg-August-Universität $\square$ zuemruet.alpinar-sencan@med.uni-goettingen.de

Gönderim Tarihi: 10.10.2017• Kabul Tarihi: 16.02.2018
} 
Bir bilimsel felsefeci olarak Yaman Örsü̈n yöntembilimsel yaklaşımı ve bunun etik ve kısmen biyoetik için öneminin ince-lenmesi, bu makalenin amacın oluşturmaktadrr. Ayrica bu makalede, görünüşe göre Yaman Örs tarafindan ilk kez düşünülüp, ortaya konmuş ve sadece tıp etiğgi ve biyoetik için değil, ayn zamanda akademik bir alan olarak

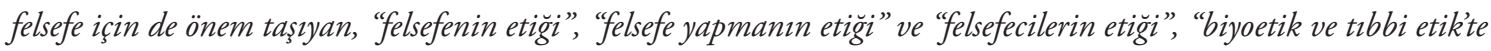
sorun kümeleri" gibi terimlerin önemi vurgulanacaktrr.

Anabtar Kelimeler: yaman örs, bilimsel felsefe, etik, felsefenin etiği, biyoetikte sorun kümeleri, etiğin farkl-laşmıs uzantiları olarak meslek etikleri.

\section{INTRODUCTION}

Yaman Örs (1936-2016), the late prominent and leading bioethicist in Turkey, is a crucial figure in the academia and a well-qualified philosopher. ${ }^{1} \mathrm{He}$ is a scientific philosopher with a background in medicine. As a pioneer in the field of bioethics and, more specifically, medical ethics, it is important to comprehend his methodology and approach to probe its role in ethics and bioethics. Hence, this paper aims to clarify his philosophical attitude and methodological approach as a scientific philosopher. This paper also aims to signify in detail the meaning of his own terms in the context of ethics and his overall approach to ethics and, in part, to bioethics.

Scientific philosophy can be understood as an academically methodological approach to philosophical activity, philosophical problems and how to deal with them. Yaman Örs argues for the importance of scientific philosophy, also when ethics and bioethics are considered. He embraces the approach of logical positivism, logical empiricism and scientific philosophy, basically as defended by Hans Reichenbach (1891-1953). In this paper, Örs's philosophical attitude and his methodological approach to ethics will be discussed. Then, I will signify, somewhat in detail, the importance of his own specific philosophical terms in this context, such as, "the ethics of philosophy", "the ethics of philosophizing", "the problem sets in bioethics and medical ethics", and "ethics of the professions as differentiated extensions of ethics", which are possibly discussed systematically, for the first time, by Yaman Örs.

\section{YAMAN ÖRS’S PHILOSOPHICAL ATTITUDE}

According to Yaman Örs, philosophy is a meta-activity in which our propositions, views and value judgments are analyzed and interpreted critically from a logico-semantical point of view $(1,2)$. To comprehend this methodological approach is quite crucial to better understand his approaches to the issues of ethics, because a philosopher's general views in the field of philosophy would significantly influence his attitude and approach to ethics (3). The aim of this section is to clarify his methodological approach briefly.

The philosophical attitude and views of Örs can be best explained by the empiricist approach. Because Örs is a scientific philosopher and scientific philosophy is an extension of empiricism (4). I think that it would be useful to draw attention to the basic differences between the two main philosophical movements, rationalism and empiricism, in this regard. Basically, the main difference or disagreement between these two philosophical movements is epistemological; that is, it lies in their approach to the source of knowledge. According to rationalistic philosophers, the source of knowledge lies in the human mind, whereas for the empiricists it should be searched in the outside world.

Örs embraces, as mentioned in the section above, the approaches of logical positivism, logical empiricism and scientific philosophy, as defended by Hans Reichenbach. ${ }^{2}$ According to the philosophical approach of the Vienna Circle, which adopted neo-positivism, the propositions of the traditional (mostly speculative, rationalistic) philosophy were unjustified $(4,5)$. In comparison, scientific propositions were falsifiable and verifiable and were based on experience and observation. For philosophical propositions to be meaningful and justified, they should be analyzed logically and semantically. This could be done by an extensive usage of 
semantic logic $(4,5)$. The crucial thing about this method is clarification of the philosophical problems and assertions. Hence, as a methodological requirement of scientific philosophy, which is nourished by the Berlin Circle (which adopted logical empiricism) and the Vienna Circle, it would be necessary for the propositions, views and judgments to be coherent and conceptually, logically, critically and semantically analyzed and interpreted; in this way, they would also be accounted for.

To avoid misunderstandings, I believe it is important to emphasize here that scientific philosophy is about methodology, about how we do philosophy (6). Contrary to the speculative propositions of traditionalist, rationalist philosophy, for scientific philosophy verifiability (meaningfulness) of the propositions is crucial. For instance, metaphysical propositions that are not based on observation or supported by experimentation would devoid of meaning and hence should be rejected. In that sense, science and philosophy are not necessarily rival activities (7); on the contrary, they are complementary activities although they differ in methodology and content $(2,8)$. Both activities aim to understand and explain the world (8). However, according to neopositivism, logical empiricism and scientific philosophy movements, philosophical activity cannot explain the empirical world in a more or less direct way, which is the main function of (basic) science $(4,7)$. Therefore, although, as Örs terms it, "the problem sets" could be seen similar, the solutions they offer to the problems and the methodologies they use would differ (8). According to these movements, and as has been put forward most systematically by Hans Reichenbach, philosophical activity cannot produce philosophical knowledge on the empirical world, which is the function of science (7). Although another kind of knowledge is produced, it is open to discussion that what kind of a knowledge it could be (8-10). This is a revolutionary approach to philosophy and science that leads to question the limits of philosophical activity (7).

It should be noted that the limits of philosophy just mentioned implies a critical attitude to philosophical activity $(4,7)$ and sheds a light on the methodological problem of philosophy. The limits of philosophy, although sounds quite negative, should not be understood to be so, since it implies the methodology that should be obtained in philosophical activity (11).

Starting from this point of view, it should be clear that according to Örs, philosophical activity should adopt the methodology of scientific philosophy and get over the influence of traditionalist, rationalist philosophy (2).

\section{UNDERSTANDING ÖRS'S METHODOLOGICAL APPROACH TO ETHICS}

After briefly mentioning his methodological approach and main attitude to philosophy, we can now consider his approach to ethics. According to Örs, ethics, or moral philosophy, basically concerns our wishes and desires as to how interhuman relationships, the relations between the individual and the society, between the latter and the state, and those between us and other beings and the biosphere as a whole should be; hence, it is essentially of a subjective nature $(9,12){ }^{3}$ Ethics does not have concrete grounds whereby we would have clear answers, as, for instance, science would provide (the truth of which may be provisional, though). Taking into consideration the different ethical / moral views differing from person to person (and from group to group, from culture to culture and so on in the case of morals) would make this subjectivist account clearer.

In the eyes of a scientific philosopher like Örs, moral philosophy or ethics can be defined as a critical inquiry into our basic concerns about our moral values, that is our wishes and desires as to how interhuman relationships should be $(9,13)$. It might be justifiably claimed that since people differ so much insofar as they have different personalities, different cultures and life-styles, hence life philosophies and views, we do observe many different moral values and ethical judgments in different societies, social groups and individuals. Thus, and although he denies relativism, he claims that ethics is at bottom subjective (embedded in a personality in a given context), and there cannot be any absolute principle that can be acceptable in every related and comparable situation (14). Hence his strong denial of objectivity in ethics or "ethical objectivity". 
Despite this subjectivist view, and since he adopts the approach of scientific philosophy and logical empiricism, we should not be surprised to find that he claims that the moral views people accept must be defensible on ethical grounds, and the related value judgements should be accountable, differently though from the propositions of science and our daily life.

I think that at this point of our discussion it would be useful to turn back to the basic differences between rationalism and empiricism, as mentioned in the section above. The traditionalist, rationalist philosophers, generally speaking, hold the view that there are unchangeable, generalizable, universal "truths" in ethics; and therefore, that it can be claimed that there is "objectivity" in the area of ethics (9). By this means, the claim that ethics can provide us objective truths is emphasized. This claim leads to the argument that since there are some universally accepted, unchanged truths in ethics, our ethical judgments can be falsifiable or verifiable, which is a basic property of scientific knowledge. Those philosophers adopting rationalistic philosophy can claim objectivity in ethics, theories in ethics, and then ethical propositions. They argue that it is possible to argue for the universal, generally accepted ethical principles. However, according to logical empiricism, as adopted by Örs, and as is the case, also, in philosophy generally speaking, in ethics it is not possible to arrive at such general, unchangeable, universal empirical truths (9). In addition to this, our moral values depend on our personality and subjectivity, as has been emphasized earlier. And therefore, in his view, open-endedness, which I will now briefly explain, is one the most important features of this branch of philosophy.

According to Örs, there are three main features of ethics which come into question when we reason and arrive at ethical judgments: Means-and-end relation, subject-object relation and open-endedness (14). The first one is about how we consider which mean(s) are moral when we want to reach an end (13). People have different ends and to reach that ends each will use a different means. Here, how one approach or considers another human or a living thing will form our ethical approach and perspective. This feature has an important role in reasoning ethical judgments. Subject-object relation considers everything (including other humans or, more generally, other living things) to which we direct our moral values. Open-endedness, being one of the most important methodological features of ethics, is involved in ethical judgements, arguments and discussions. Ethical discussions involve our differing moral values, attitudes, approaches, and our interests in social life in the most comprehensive sense of the term. Consensus would certainly play a significant role in ethics, in political discussions for instance, in order to solve the problems raised by conflicting values and interests. Besides, when a possible solution is considered for the ethical problem at hand, a decision-making process occurs and the ethical decisions is going to be made after a choice. It is important to signify that every ethical decision-making process would bring about both negative as well as positive outcomes, which would also be the case in the other possible choices left behind (15). Ethics and morality seem to be context-dependent as well as subjective. Whichever option you choose, there will be an ethical residue left behind, which means exactly that there are no perfect ethical choices.

\section{ON ÖRS'S OWN PHILOSOPHICAL TERMS}

Having briefly explained Örs's methodological approach to ethics, we can now continue by discussing some of his own specific philosophical terms.

As it is called "applied ethics" by philosophers, and "ethics of the professions" by the members of other professions, there is a subbranch of ethics which critically inquires the attitudes, behaviors and activities of professional people in relation with their activities. According to Örs, either "applied ethics" or "ethics of the professions" are "differentiated extensions of ethics" (13). The chief reason why such a qualification is needed, according to Örs, is mainly the inevitable existence of certain peculiar features found in each profession I professional activity, including all academic fields. Thus, for each profession there exist ethical problems peculiar to that profession (9). As we know, there are so many different kinds of such professions. In the 
light of more or less specific moral problems faced by each profession, there occur different "moral problem sets" peculiar to each professional activity (16). Within the limits of these problem sets, each member of different professions would endeavor to find an answer to the ethical problems / moral dilemmas faced by the profession. International deontological principles and legal rules apart, the diversification of possible answers to moral dilemmas can understandably be explained, when professional people with different cultural background come with different approaches, perspectives and possible answers to ethical problems, only by the open-endedness and essentially subjective nature of ethics (9). Therefore, as argued by Örs, it would be helpful to focus on the specific moral dilemmas peculiar to each profession and to find possible answers to those to analyze the problem sets of each profession conceptually, not to dismiss, of course, with the universal and generally accepted "overall" ethical principles; such a multi-aspect approach seems to provide the best methodological solution to the ethics of the professions.

If we reconsider the definition of "differentiated extensions", it would be claimed that there occurs a difference in the moral problems, and therefore in the problem sets, which may come up due to the professional differences between, say, a surgeon and a clinical researcher towards her patient and her experimental subject, respectively (17). As argued by Örs, on the one hand, and due to the different perspectives of different persons and members of the different professions, there occur different moral / ethical problems, each of which would require different analysis on its own sake and in its own context; on the other hand, these problems will generate problem sets created by the similarities between them (16).

Now, I would like to consider another philosophical term, which seems to be raised first by Örs: "The ethics of philosophy or philosophizing". By the word "ethics" used in such terms as "the ethics of philosophy" and "the ethics of philosophizing", he does not signify a subbranch of philosophy, but how philosophy ought to be critically considered from an ethical point of view $(18,19)$. If we consider the ethics of philosophy or philosophers as a subclass of the ethics of professions, then such questions might be asked: Can philosophers be held responsible for the judgments they arrive at? Or, in other words, can they stand by their judgments and perspectives from the point of ethics?

What Örs wants to signify is whether the philosophers, who seem to have the right, supposedly, to criticize almost all the activities of different professions and fields from the point of ethics as well, should not also be critical about their own activities. Here, especially whether the language philosopher's use is understandable, clear or not, and whether the ideas that are brought about and their justifications are presented clearly enough is argued for (20). Needless to say, this would include the methodological approach of philosophy considering academically what and how to do, and how the arrived judgment or idea should be justified and which one would be more acceptable. This would also bring the point, in its wake, whether the philosopher himself should or should not have an "accountable" attitude to the products of his/her own activity. According to Örs, philosophers should give their justifications / reasons clearly for their values, judgments, views, etc., that they argue, and this will lay an ethical burden on them $(18,19,21)$. The main concern of Örs is whether the philosophers who are adopting the rationalistic philosophy's approach will be able to reason clearly enough about their own intellectual activities and their products.

\section{CONCLUSION}

Throughout the paper, I have endeavored to examine clearly and briefly Örs's methodological approach as a scientific philosopher and the significant role it plays in ethics. To do that, I began by focusing on his philosophical attitude and methodological approach as a scientific philosopher. Then, after briefly explaining his methodological approach, I continued by probing how this would influence his approach to ethics by signifying in detail the meaning of his own terms in the context of ethics. I also endeavored to show the importance of his own specific philosophical terms in this context. 
As mentioned at the very beginning of the paper, Yaman Örs is a pioneer in bioethics who has a crucial effect on the development of this academic field in Turkey. He has worked on many topics which are not limited to the topic of this paper. ${ }^{4} \mathrm{He}$ has a great number of published works in which he covered the importance of scientific philosophy for the philosophical activity, the methodology in ethics and the moral issues arising in the field of bioethics and medical ethics. It is impossible to mention all of them in this paper. By referring to some of his selected works, this paper endeavored to probe his methodological approach and the significant role it plays in ethics and bioethics.

His works on the methodology of philosophy and ethics is quite important not only for philosophy of medicine, medical ethics and bioethics, but also for philosophy as an academic field of study. This is mostly emphasized by, probably, his own specific terms "the ethics of philosophy or philosophizing" as tried to be explained in the last section of this paper.

\section{ACKNOWLEDGEMENTS}

I am very thankful to Prof. Dr. Yeşim Işıl Ülman for her valuable suggestions that helped me further develop this paper. I would like to express my gratitude to my mentor in Philosophy and Bioethics, to Prof. Dr. Yaman Örs, who I remember with utmost respect, for his guidance over the course of many years.

\section{REFERENCES}

1. Örs Y. Hangi felsefe? Felsefe Tartışmaları. 1989 May; 5. p. 112-120.

2. Örs Y. Felsefe ve anti-felsefe. Cumhuriyet Bilim Teknik. 1999 Feb; 620:15.

3. Alpınar Z, editor. Giriş: Kısaca, Yaman Örs’ün felsefi bakış açısı. In: Alpınar Z, editor. Bir bilimsel felsefeci olarak Yaman Örs’ün yaklaşımıyla etik’ in anlamı ve anlmasızlığı. Ankara: Efil Yayınevi; 2011. p. 3-4.

4. Örs Y. Bilim ve bilimsel felsefe çevresi’nin akademik yaklaşımı. In: Şahinoglu S, Arapgirlioğlu K, Çelebi $\mathrm{H}$, Örs Y, editors. Bilimden felsefeye akademik bir çevrenin serüveni: Bilim ve bilimsel felsefe çevresi. Ankara: Bilim ve Gelecek Kitaplığı; 2011.p. 44-61.

5. Örs Y. Felsefeye karşı felsefe: Neden bilimsel felsefe ve neden Hans Reichenbach? In: Günay M, editor. Arslan Kaynardağ a Armağan - Türkiye’de Felsefenin Kurumlaşması. İzmir: İlya İzmir Yayınevi; 2006. p. 330-346.

6. Örs Y. Hans Reichenbach ve bilimsel felsefe. In: Şahinoglu S, Arapgirlioğlu K, Çelebi H, Örs Y, editors. Bilimden felsefeye akademik bir çevrenin serüveni: Bilim ve bilimsel felsefe çevresi. Ankara: Bilim ve Gelecek Kitaplığı; 2011. p. 227-241.

7. Örs Y. Biomedical ethics and the limits of philosophy. In Kuçuradi I, editor. Ethics of the professions: Medicine, business, media, law. Springer: Berlin and so on; 1999. p. 36-47.

8. Örs Y. Felsefe konusunda geleneksel tutum ve temel yanılgılar. Bilim ve Ütopya. 2000 Oct;76:32-37.

9. Örs Y. Uygulamalı ve uygulamasız etikte 'etikçiler' aranıyor. In: ODTÜ II. Uygulamalı Etik Kongresi (18-20 Ekim 2006) Kitabı. Ankara; 2007. p. 496-503.

10. Örs Y. Bilimsel felsefe ve siyasal yaşam. In: Şahinoglu S, Arapgirlioğlu K, Çelebi H, Örs Y, editors. Bilimden felsefeye akademik bir çevrenin serüveni: Bilim ve bilimsel felsefe çevresi. Ankara: Bilim ve Gelecek Kitaplı̆̆ı; 2011. p. 547-558.

11. Örs Y. Felsefe ve sınırları. Felsefe Tartışmaları. 1994 Jan; 15. p. 63-71. 
12. Örs Y. Etik konusunda geleneksel tutum ve temel yanılgılar. In: Mengi A, editor. Ruşen Keleş’e Armağan -Demokrasi ve Politika; Hukuk, Yönetim ve İktisat Üzerine. Ankara: İmge Kitabevi; 2007. p. 397-408.

13. Örs Y. Etikte genel ilkeler. In: Çavdar, AO, editor. TÜBA Kanser Çalışma Grubu, Kanser Etiği Sempozyumu (15 Aralık 2003) Kitabı. Ankara: Türkiye Bilimler Akademisi Yayınları; 2004. p. 13-20.

14. Alpınar Z, editor. Giriş: Yaman Örs'ün etik anlayışı. In: Alpınar Z, editor. Bir bilimsel felsefeci olarak Yaman Örs'ün yaklaşımıyla etik’ in anlamı ve anlmasızlığı. Ankara: Efil Yayınevi; 2011. p. 51-52.

15. Örs Y. Bilgi-etik koşutsuzluğu ya da Sokrat' in bir teması üzerine karşıt çeşitlemeler. Felsefe Tartışmaları. 1994 Dec; 17. p. 117-126.

16. Örs Y, Büken NÖ. Tıbbi etikte sorun kümeleri. In: Şahinoğlu $S$ ve ark., editors. 3. Tıbbi Etik Sempozyumu (23-25 Ekim 1997) Kitabı. Ankara: Biyoetik Derneği Yayınlari; 1998. p. 3-8.

17. Örs Y. Tipta etik ve insan hakları. 3P (Psikiyatri, Psikoloji, Psikofarmaloji) Dergisi. 1993; 3:270-277.

18. Örs Y. Felsefenin etiği / felsefecilerin etiği. Çağdaş Türk Dili. 2004 Nov; 201:465-467.

19. Örs Y. Felsefe yapmanın etiği (Ethics of philosophizing). In Cevizci A., editor. Felsefe ansiklopedisi. Ebabil Yayınları: Ankara; 2009. C. (Vol.) 6.

20. Alpınar Z, editor. Yaman Örs’ün yaklaşımıyla konuya giriş. In: Alpınar Z, editor. Bir bilimsel felsefeci olarak Yaman Örs'ün yaklaşımıyla etik'in anlamı ve anlmasızlı̆̆ı. Ankara: Efil Yayınevi; 2011. p. 115-116.

21. Örs Y. Uygulamalı etik, uygulamasız etik ve felsefe yapmanın etiği. In: 1. Ulusal Uygulamali Etik Kongresi (ODTÜ, 12-13 Kasim 2001) Kitabı. Ankara: ODTÜ Felsefe Bölümü; 2003. p. 247-254.

\section{Endnotes:}

1 He is among the founders of the Turkish Bioethics Association (established in 1994). He also has played a leading role in the establishment of the Circle for Science and Scientific Philosophy (2000-2004) which is formed by academicians from different fields and with different academic levels. Additionally, between 1989 and 1993, he was a member of CDBI (Comité Directeur sur la Bioéthique) at the council of Europe as the Turkish representative.

2 Here, it should be noted that scientific philosophy should not be mistaken for philosophy of science. Scientific philosophy is a term about methodology and approach, and therefore, signifies a specific philosophical movement while philosophy of science is a sub-field of philosophy.

3 In his works, when Yaman Örs refers, for instance, "ethics" as an academic field, then he writes the term in capital letters. However, to avoid confusions, this will not be followed in this paper.

4 He has a wide variety of research interests including the methodological aspects of science, history, philosophy, medicine, ethics, psychiatry, the concept of evolution and the inter-disciplinary field of psychiatry and philosophy. He also has works on academic-professional and popular-intellectual levels about medicine and biology, ecology and history, socio-political as well as medico-social issues, secularism and the problems of language and the language of science. 